ERRATUM

„Polish Journal of Environmental Studies"

Vol. 25, No 1 (2016), 27-35

\title{
Monitoring Cyanobacteria Blooms in Freshwater Lakes using Remote Sensing Methods
}

\begin{tabular}{|c|c|}
\hline IS: & SHOULD BE: \\
\hline Katarzyna A. Kubiak $^{1,2}$, & Katarzyna A. Kubiak $^{1,2}$, \\
Jan Kotlarz $^{1,3}$, Anna M. Mazur $^{1 *}$ & Jan Kotlarz $^{1,3}$, Pawel Czapski $^{1}$ \\
Anna M. Mazur & ${ }^{1 *}$ \\
\hline
\end{tabular}


ERRATUM

„Polish Journal of Environmental Studies”

Vol. 25, No 1 (2016), 27-35

\section{Monitoring Cyanobacteria Blooms in Freshwater Lakes using Remote Sensing Methods}

\begin{tabular}{|c|c|}
\hline IS: & SHOULD BE: \\
\hline $\begin{array}{c}\text { Katarzyna A. Kubiak }{ }^{1,2} \\
\text { Jan Kotlarz } \\
\text { K, , Anna M. Mazur }{ }^{1 *}\end{array}$ & $\begin{array}{c}\text { Katarzyna A. Kubiak }{ }^{1,2}, \\
\text { Jan Kotlarz }^{1,3} \text {, Pawel Czapski }{ }^{1} \\
\text { Anna M. Mazur }{ }^{1}\end{array}$ \\
\hline $\begin{array}{c}\text { 'Institute of Aviation, } \\
\text { Al. Krakowska 110/114, 02-256 Warsaw, Poland } \\
{ }^{2} \text { Forest Research Institute, Skocin Stary, } \\
3 \text { Braci Leśnej, 05-090 Raszyn, Poland } \\
{ }^{3} \text { Warsaw University Observatory, } \\
\text { Al. Ujazdowskie 4, 00-478 Warszawa, Poland }\end{array}$ & $\begin{array}{c}\text { 'Institute of Aviation, } \\
\text { Al. Krakowska 110/114, 02-256 Warsaw, Poland } \\
{ }^{2} \text { Forest Research Institute, Sękocin Stary, } \\
3 \text { Braci Leśnej, 05-090 Raszyn, Poland } \\
{ }^{3} \text { Warsaw University Observatory, } \\
\text { Al. Ujazdowskie 4, 00-478 Warszawa, Poland }\end{array}$ \\
\hline
\end{tabular}




\title{
Monitoring Cyanobacteria Blooms in Freshwater Lakes using Remote Sensing Methods
}

\author{
Katarzyna A. Kubiak ${ }^{1,2}$, Jan Kotlarz ${ }^{1,3}$, Anna M. Mazur ${ }^{1 *}$ \\ ${ }^{1}$ Institute of Aviation, \\ Al. Krakowska 110/114, 02-256 Warsaw, Poland \\ ${ }^{2}$ Forest Research Institute, Sękocin Stary, \\ 3 Braci Leśnej, 05-090 Raszyn, Poland \\ ${ }^{3}$ Warsaw University Observatory, \\ Al. Ujazdowskie 4, 00-478 Warszawa, Poland
}

Received: 6 August 2015

Accepted: 14 October 2015

\begin{abstract}
Anthropogenic lake eutrophication can allow toxic cyanobacteria (blue-green algae) to grow uncontrollably, resulting in harmful algal blooms with potentially serious economic and health-related impacts. Development of monitoring methods for predicting bloom events is an important goal of monitoring programs and is one of the fundamental interests to those examining the ecology of aquatic ecosystems. Implementation of new monitoring methods complies with the provisions of national and community laws for the protection and restoration of good chemical and ecological status of water reservoirs and dependent ecosystems, and allows for the fulfilment of obligations of legislation policy of European Union (WFD 2000/60/EC) and Polish Water Law Acts, and The Environmental Protection Law. Our paper investigates a comparison between aerial remote sensing methods and currently used technology, and presents advantages of the proposed monitoring as an accurate, flexible, cheap, and fast method of detecting and predicting eutrophication and therefore cyanobacteria bloom in water reservoirs, taking into account the complexity and dynamics of an ecosystem. The article also states that aerial remote sensing technology represents an innovative tool strongly supporting traditional methods for continuous monitoring application and an early warning system against algal bloom. Therefore, it is reasonable to continue remote sensing methods development in order to precisely determine the cyanobacteria blooms in lakes. It is also necessary to improve satellite algorithms and the use of both satellite images and those taken from unmanned aerial vehicles (UAVs) and manned planes.
\end{abstract}

Keywords: cyanobacterial bloom, remote sensing, eutrophication, UAV, satellite images

\section{Introduction}

Remote sensing monitoring of cyanobacteria blooms in lake water bodies has made great progress all over

*e-mail: anna.mazur@ilot.edu.pl the world in satellite remote sensing for estimating the concentration of cyanobacteria bloom in coastal waters of the sea and oceans. Particularly important is that satellite remote sensing methods allow for the simultaneous measurement of multiple water bodies such as oceans, seas, and large water reservoirs, but this methodology 
cannot be simply transferred into inland monitoring especially in Poland [1].

Algorithm development for remote monitoring of water bodies such as shore waters, littoral zone waters, rivers, and lakes is difficult due to the complexity of the multilateral coastal zone designated by the complexity of biological and optical parameters that consist of spatial and temporal ecosystem dynamics. In addition, shore waters are often shallow, so the reflectance bottom is a component of water-leaving reflectance. Moreover, benthic plant communities with different structure and depth affect the registered outgoing reflectance signal. In the littoral phytoplankton zone suspended solids concentration is much higher than in "blue" ocean waters. An additional difficulty is the variability of the spectral characteristics of different types of phytoplankton and suspensions that can strongly modify a registered spectral reply [2].

Furthermore, the spectral characteristics of phytoplankton and suspensions overlap each other in such a way that it is necessary to develop specific algorithms for extracting the information relevant to coastal waters [3].

Factors implying biological complexity are: the presence of multicellular algae, the density of communities of invertebrates, and seasonal development of biomass. Spectral properties of coastal waters are dominated by the content of the various components, which are different from the properties of open ocean waters where light scattering dominates. This is evident in the case of chlorophyll, which is present in coastal waters and can be several times more concentrated than in the oceans. As a result, the algorithms used for determining the chlorophyll content of satellite observations in the open ocean waters "break down" in coastal areas with a high concentration of pigments and at high concentrations and types of different water suspensions $[1,4,5]$.

Because of these characteristic elements for freshwater Polish lakes the general algorithms developed so far are not very accurate. Therefore, innovative remote aerial sensing methods for cyanobacteria bloom monitoring and early prediction are proposed, which are definitely more accurate. The introduction of innovative methods allows a substantial improvement in the quality of research.

\section{Environmental Problem}

Eutrophication is an ecological problem that results in visible cyanobacteria blooms that degrade the physical and chemical characteristics of water, disturbing the ecology and biodiversity of aquatic ecosystems.

Blue-green algae produce cyanotoxins that are dangerous to flora and fauna of freshwater reservoirs and are harmful for human bathing and drinking water supplies [6]. The bloom phenomenon arrival is extremely timely because new challenges in the field have appeared recently, including emerging toxins and cyanobacterial species hitherto unknown in Poland and other European countries. In Poland, cyanobacterial blooms in the water supply is a major problem, especially for the Mazury Lake District in northeastern Poland [7], where a significant anthropogenic impact on the aquatic environment has been identified. Agriculture is one of the major sources of eutrophication [8]. Impact on water quality is manifested in the form of: increased content of nitrates and phosphates in surface and groundwater, the chemical residues of plant protection products, and silting of water displacing soil particles by water erosion. Leachate from landfills contains high mineralization levels and is characterized by significantly elevated biological and chemical oxygen demand (BOD, COD), and high concentrations of dissolved solids, chlorides, sulfates, and ammonium nitrogen compounds [9].

The existence of cyanobacteria in aquatic ecosystems dramatically changes water ecosystem structure by affecting the distribution of host species, modifying physical and chemical characteristics, reducing the availability of resources, and providing habitat for associated organisms. Blue-green algae can lead to deterioration of water quality and use up the oxygen, causing the death of fish [8]. The cumulative effects of eutrophication and warming of the aquatic environment, coupled with cyanobacterial blooms, threaten the long-term survival of clean and cold-water fish species in the Mazury Lake District. Human illness due to cyanobacterial toxins may cause either short-term or long-term injury or chronic health effects $[10,11]$. Even minor contact with cyanotoxins in bathing water can lead to allergic reactions, skin irritation with deep blistering, increased probability of gastrointestinal symptoms, and even direct responses to toxins [12]. Illnesses from accidental swallowing of cyanobacteria during swimming include headaches, nausea, muscular pains, painful diarrhea, vomiting, flu symptoms, skin rashes, mouth ulcers, severe pneumonia, fevers, central abdominal pain, blistering of the lips, sore throat, and eye or ear irritations within several days following exposure [13]. Symptoms can increase with duration of water contact and cell density of cyanobacteria. The possibility of carcinogenesis and tumor growth promotion has been shown in animal experimentation and needs further evaluation [14].

For example Planktothrix spp strains are one of the most abundant in Polish water bodies and dominant in some Mazury lakes. The population of Planktothrix agard in some water bodies constituted over $90 \%$ of the phytoplankton biomass, from early spring to late autumn, and sometimes even in winter [15-17]. Planktothrix genera produce large number of toxins harmful to humans, animals, and ecology [15, 16, 18, 19]. Production of microcystins (MC), aeruginosins, anabaenopeptins, and other peptides by $P$. agardhii is common among European water bodies, including Polish (approximately $90 \%$ of the population in various lakes contain toxicity genes) $[16,20$, 21]. However, within the Planktothrix community, both toxic and non-toxic strains can be found, and the proportion of microcystin encoding genes ( $m c y)$ to the abundance of Planktothrix populations in several European lakes was stable, regardless of the season and the density of the total population [20]. Therefore, in Planktothrix-dominated lakes, the microcystin concentration can be estimated based on the size of the Planktothrix population [16]. So, the 
presence and growth rate of this species in the cyanobacteria community could be used as supporting information for early warning systems about the toxic bloom.

Environmental abiotic conditions and physiological stress has affected the stability of microcystin profiles among the strains in different ways, and may affect the disappearance of toxins with low-intensity signals [17]. In many studies, it has been proven that environmental conditions have only minor and indirect effects on toxin production $[16,22,23]$. The toxicity of the bloom depends on the genetic diversity of the cyanobacterial species and the contribution of the toxin-producing strains [16, 24]. Therefore, only the factors that favor growth of the toxic strains can have an effect on sanitary conditions of water bodies $[16,25]$. Remote sensing methods for identification and probably even estimation of diversity of cyanobacteria in the phytoplankton community can be extremely valuable information for researchers, government institutions, public organizations, and private visitors involved in monitoring algal blooms for public health protection.

The structure and dynamics of cyanobacteria population (and cyanotoxins) in Polish water bodies have been described in numerous papers published in the last two decades [15, 16, 26-60]. Research study and regular cyanobacteria bloom monitoring in Poland rely on analytical laboratory methods: microbiology, biochemistry, physicochemical analysis of water, toxicology, microbial ecology, and molecular biology [61-66]. The rapid development of analytical methods and research caused prompted the introduction of remote sensing methods needed to create added value for traditional technology, allowing for substantial improvement in the quality of research.

In recent years signature spectral analysis for biomass productivity estimation and environmental monitoring has become more popular either by use in situ or remote sensing technology. In situ methodology includes fluorescence analysis of photosynthetic pigments that determine: the concentrations of chlorophyll a, phycocyanin, phycoerythrin, carotenoid, and xanthophylls; microscopy and genetic analysis for determining the composition and structure of the phytoplankton community with particular regard to participation; the calibration of fluorescence of photosynthetic pigments and biodiversity cyanobacteria species in waters; and examination of the fluorimetric signature of the pure strains of major taxa occurring in the studied reservoirs that are isolated from these lakes and other typical lakes (cyanobacteria, green algae, diatoms, dinoflagellates). The results of these analyses should reveal the proportion of cyanobacteria species, distinguish toxic and non-toxic cyanobacterial genera, and monitor cyanobacterial species with specific physiological structures like aerotops (based on their fluorescence and reflectance) $[67,68]$.

A major problem in the Polish monitoring system is a lack of spatial, innovative monitoring methods of cyanobacterial bloom in inland freshwaters. At the same time they reflect growing awareness of the complexity of the processes in nature that must be taken into account in the introduction in new monitoring methods. In recent years innovative telemetry large-area monitoring methods are becoming a more important, useful, and available tool in environmental monitoring systems $[69,70]$. Algorithms developed for remote satellite monitoring of cyanobacteria blooms in sea and ocean water are well described but are not accurate for inland waters such as shore waters, littoral zone waters, rivers, and lakes. Because of the complexity of the multilateral coastal zone, there is a need to develop a sensitive method to monitor spatial and temporal ecosystem dynamics [71].

\section{Environmental Policy/Legal Basis to Improve Water Quality}

The obligation to maintain or improve the conditions of inland freshwater reservoirs, water protection, and monitoring are implemented by Polish and European legislation. Eutrophication and cyanobacteria bloom has become a focus of concern in Europe and therefore it is very important to take actions to control and maintain the best performance of freshwater reservoirs. Environmental policy within the European Union in the field of water resources focuses on protecting and restoring clean water across Europe in order to achieve good chemical and ecological status enabling sustainable use. The implementation of the Water Framework Directive (WFD 2000/60/EC of the European Parliament and of the Council of 23 October 2000 establishing a framework for Community action in the field of water policy) [72] forces a change in approach to quality of the structure and functioning of aquatic ecosystem monitoring. Monitoring should be conducted in the context of adapting to the requirements of the WFD with records of surface water monitoring, leading to achieving the goal of good chemical and ecological status and integration of needs of various sectors of the national economy with the needs of the environment. According to the WFD, new methods should address inland surface waters and should establish an innovative approach for water monitoring, including public participation in planning and economic approaches. Monitoring should be carried out in accordance with the Regulation of the Minister of Environment of 13 May 2009 on forms and methods of conducting surface water and groundwater monitoring (OJ of 2009 No. 81, item. 685). From 15 November 2011 a new regulation came with the same title (OJ of 2011 No. 258, item 1550) [73]. Additionally, monitoring and research should be carried out in accordance with, i.e., the provisions of Water Law Acts [74] and the Environmental Protection Law, together with Regional Environmental Protection Programmes in order to obtain information on the status of surface water quality for the evaluation of achieving environmental objectives.

\section{Remote-Sensing System Techniques}

Remote sensing obtains an optical measure of water color and turbidity (pollutants must affect color or turbidity to be detectable). Dissolved colored materials 
increase the absorption of light in water and decrease the remote signal, whereas suspended materials increase the backscatter of light and increase the remote signal. The major problem is that a backscattered flux may represent a mix of water color, bottom reflectance, turbidity produced by plankton, and turbidity caused by suspended sediment. In many cases, however, a change in flux is caused simply by a change in the concentration of one constituent. A number of studies have shown only a fair correlation of remotely measured flux and water turbidity [75-77].

The main reason probably is lateral and vertical variations in water turbidity, but deviations also may be introduced by the manner in which turbidity is measured on the ground. A remotely measured energy level may be a more accurate representation of average, near-surface turbidity than laboratory analysis of a point sample. Factors that must be evaluated in deciding upon satellite surveillance of water quality are feasibility, cost, and value of information content. Turbidity and color are only two of many constituents and characteristics of terrestrial water. From this viewpoint, satellite remote sensing may not compare favorably with conventional procedures, wherein a single water sample can be analyzed for many constituents. However, remote sensing offers considerable advantages for the study of large areas, determination of current and circulation patterns and monitoring of sedimentation, water productivity, and eutrophication. A set of algorithms has been developed for MERIS, MODIS, or SeaWiFS satellite data analysis by the National Oceanic and Atmospheric Administration (NOAA) [78].

Their main goal is to estimate chlorophyll, dissolved organic carbon, and suspended minerals - the three primary color producing agents of water environment. The algorithms utilize a specific hydro-optical model for each water area. The hydro-optical models provide absorption functions for all three components as well as backscatter relationships for the chlorophyll and SM, and were generated using in situ optical data collected with coincident water chemistry (concentration) measurements. These new algorithms provide more accurate chlorophyll values then those obtained using the standard OC3 NASA MODIS retrieval when compared to in situ cruise observations, as well as providing the additional information on dissolved organic carbon and suspended minerals. The best methodology is to improve those algorithms and use not only satellite images, but also images taken from UAVs and manned planes by a multispectral platform [79].

\section{Remote-Sensing Satellite Data Acquisition}

There are quite a few good phytoplankton and cyanobacteria characteristic models, but they are usually applicable only for satellite data, not UAVs or manned plane cameras, i.e.:

- Chlorophyll-a model: there is quite a big spectral signature difference of reflected light between water with and without algae. For determining chlorophyll-a concentrations, a R/NIR ratio is proposed that theoretically produces the same 'relatively' normalized value of $600-700 \mathrm{~nm}$ radiance $[31,32]$

- Cyanobacteria model: Landsat ETM+ data analysis results confirm that the same combinations of single bands and band ratios used in the final Chlorophyll-a models were also most significant in predicting cyanobacteria biovolume. Generally, the model performed well at detecting cyanobacteria biovolumes above $0.05 \mathrm{~mm} 3 \mathrm{~L}-1$, although the model prediction at lower concentrations is not as good, sometimes predicting negative concentrations when in situ levels fall below $0.01 \mathrm{~mm}^{3} \mathrm{~L}-1$ Secchi $[1,80]$

- Depth Model: Based on the results of the step-wise regression performed for 2006 Secchi depth coincident pairs, the best models also employed the same single band and band ratio combinations determined for the final chl-a and cyanobacteria models $[1,80]$

Public access to the full archive of Landsat satellite data and the availability of environmental datasets provide many opportunities for ecological and environmental monitoring. Three remote sensing models presented here were developed from coincident field sampling and Landsat ETM+ images. The results confirm that Landsat $\mathrm{ETM}+$ data can be used to provide water coverage of chl-a and cyanobacterial blooms [1,80]. The applicability of this set of algorithms for multispectral images taken from manned aircraft is the major concern. Validation of this methodology should be done by studying the correlation between cyanobacteria blooms, and biodiversity of the coastal environment and agricultural activity, including activities associated with the analysis of surrounding lakes with particular regard to landscape features affecting the eutrophication of lakes (sculpture, soil, vegetation, method of use). Based on the existing database (aerial photos, satellite maps zoning), representative areas should be proposed on which natural evaluation will be carried out with regard to the composition of plant communities and biodiversity. Inventory should be made of plant communities in the littoral zone (rushes, the zone of plants with floating leaves, submerged plants) and surrounding reservoirs, including natural ecosystems: forests, reeds; semi-meadows, pastures, anthropogenic farmland, and wasteland. Based on our research, the type and agricultural land-use intensity and grassland should be updated. In selected lakes water chemistry research should be done (mainly the content of biogenic elements N, P). Also, the physical characteristics of the soil surrounding these areas where vegetation should be mapped. Correlation analysis of the data should be made based on:

- The presence of potentially toxic cyanobacteria and cyanotoxins concentration

- The parameters of the aquatic environment measured using remote sensing and in situ data

These results are subjected to statistical analysis and associated with the measured parameters of the biodiversity of the litoral ecosystems. 


\section{Remote-Sensing UAV Photogrammetric Flights and Communication}

Photogrammetric flight can be carried out either with the use of manned or unmanned aircraft capable of carrying multispectral camera, acquiring images during the flight. Depending on the adopted methodology, altitude will be verified. When performing photogrammetric raids significant amounts of multispectral data will be recorded and preliminarily analyzed on the platform. Due to sensitivity differences of multispectral detectors, each of them must be calibrated before performing photogrammetric raids. The calibration process takes into account the quality of acquired photogrammetric data of current meteorological parameters and short meteorological forecasts. These parameters are particularly important for determining atmospheric correction factors that have a significant and direct impact on the quality of collected data. In addition, calibrating each detector sensitive to electromagnetic waves of the appropriate length will allow performing photogrammetric raids with desired quality only if meteorological conditions remain unchanged and therefore during the illumination uniformity of an investigated area [81].

Otherwise, the photogrammetric raid must be repeated and all activities related to preparation of a photogrammetric mission, i.e., the calibration process of multispectral sensors, iterative preparation of meteorological forecasts, etc. Ensuring the quality of acquired multispectral images, taking into account the uniqueness of registered electromagnetic spectrum of investigated areas, requires parameters of each multispectral sensor to be adjusted remotely. Thus, due to the uniqueness of each photogrammetric raid preliminary analysis and test parts of acquired multispectral data should be transmitted to the ground station during a raid.

Therefore, a radio communication system with a high level of reliability and adequate bandwidth should be developed and created from scratch in order to meet the requirements of acquiring multispectral data applied into a radio data link. Due to significant distances (from the point of view of a radio communication system that should operate at least in the beginning of the GHz band in order to ensure adequate bandwidth) between investigated areas location of ground stations should be selected in the manner to:

a) Allow necessary monitoring operating parameters of multispectral platform regardless of the distance to ground station

b) Allow obtaining full bandwidth of the radio link - to transfer photogrammetric data without significant delay during raids in proximity to the ground station

Therefore, location selection of the ground station should be preceded by comprehensive studies on radio coverage that will allow us to define general radio communication system requirements, such as the minimum number of ground stations that will guarantee a stable telemetry radio link with multispectral platform and radio communication system operation parameters (necessary power level at both sides of the radio link, type and parameters of antenna) in order to ensure an undisruptive telemetry radio link, and full-bandwidth radio link during flights in the very proximity to the ground station.

The designed radio communication system should be used only for remote access to the multispectral platform, and communications system cannot affect operation of other radio devices installed onboard the aircraft. Due to the uniqueness of photogrammetry raids, as well as the required high reliability of the radio link, the radio communication system should have a separate power supply and a separate antenna system. It also should ensure a stable telemetry link up to $10 \mathrm{~km}$ and a high-bandwidth (at least $1 \mathrm{MB} / \mathrm{s}$ ) link up to $3 \mathrm{~km}$; however, the permanent operational range of full capacity radio link should be not less than $1 \mathrm{~km}$. Required operating range will allow passing results of preliminary analysis immediately after acquiring photogrammetry data, i.e., in an online manner, and without landing aircraft in order to download the material offline [81].

\section{Satellite and Aerial Remote-Sensing Methodology Comparison}

The innovation of remote-sensing monitoring technology lies in providing a more accurate, flexible, cheaper, and faster monitoring method of detecting and predicting eutrophication and, therefore, cyanobacteria bloom in water reservoirs compared to currently used technology, which is becoming less relevant. The innovative aerial method distinguishes itself by continuous monitoring and multifunction of the proposed multisensory platform, which is broadly applicable not only to various aerial vehicles, manned and unmanned, but also in the laboratory and providing better, more frequent, and accurate detection compared to the use of satellite imagery $[82,83]$.

Using aerial remote sensing technology in order to monitor cyanobacterial bloom has incomparable advantages other methods do not have. It can rapidly and in a timely manner provide the whole lake or whole area's water bloom distribution status. Aerial photographs can be extracted much more frequently than a satellite scene. Preparation of air missions for the remote-controlled aircraft takes less than one hour, while for manned aircraft flight preparation is a maximum of a few hours. Observation of the natural changes requires frequent observation that can be provided by aerial remote sensing technology. Depending on the type of research required, observations can take place even several times during the day. Time to re-acquisition satellite scenes from the same area may even take several days. Images from manned and unmanned aircraft allow better and more accurate detection of smaller objects compared to the use of satellite imagery. Ground sampling distance (GSD) of sensors mounted on airplanes is much more accurate than the GSD of photos acquired with satellites systems. The resolution of aerial images can be up to several centimeters, which depends 
on flight level and type of camera. In the case of satellite scenes, for most of the solutions it is not possible to change the GSD $[82,83]$.

Satellite images are increasingly common in all kinds of applications on environmental monitoring, however, they are still expensive and have quite difficult access to the part of the pictures. The acquisition of high resolution aerial photographs $(\mathrm{GSD}<50 \mathrm{~cm})$ is much cheaper than buying satellite scenes. Mounting the camera on an airplane can provide immediate monitoring. A manned or unmanned plane can take off and gain pictures shortly after the decision to fly or just after a critical event occurrence, i.e., a natural disaster. Cameras that are mounted and used onboard manned and unmanned aircraft may also be used in the laboratory in order to obtain information about the studied objects by creating spectral reference curves that are closely related with the curves obtained during the flight (only taking into account the influence of the atmosphere). The costs of acquiring multispectral aerial images are lower than in the case of satellite scenes and therefore are available not only for local governments and research institutes but also for different businesses [82, 83].

\section{Conclusions}

Toxic cyanobacterial blooms in aquatic ecosystems and water reservoirs are potential health hazards. Therefore, predicting bloom outbreaks is an important goal of continuous monitoring and prevention of cyanobacterial blooms. The introduction of new monitoring methods is a necessity affected by the increasing impact of human activity on the environment, the advancement of knowledge, and research methods. Methods that today may still seem too complicated and too expensive are getting cheaper systematically and becoming economically viable due to the rising costs of maintaining high environmental status. At the same time, they reflect growing awareness of the complexity of the processes in nature that must be taken into account in the introduction of new monitoring methods. The introduction and evaluation of innovative methods is needed and can provide an added value for traditional monitoring methods, allowing for a substantial improvement in the quality of research.

Aerial remote sensing technology can provide more accurate, flexible, cheaper, and faster monitoring methods of detecting and predicting eutrophication and therefore cyanobacteria bloom in water reservoirs compared to currently used technology. The innovative aerial method distinguishes itself by the continuous monitoring and multifunction of the proposed multisensory platform, which is broadly applicable not only to various aerial vehicles, manned and unmanned, but also in the laboratory, and providing better, more frequent, and accurate detection compared to the use of satellite imagery. The application of the new methods and their further verification by comparison of the results from different methods is highly recommended in order to enable continuous monitoring and introduce an early warning system against algal bloom development.

The developed algorithms can provide an innovative compressive analysis of physical, chemical, and biological parameters of lake water quality and catchment in order to predict cyanobacteria bloom and generate data for an early warning system application. Currently, analysis of water quality is performed separately. The algorithms reach high precision and applicability, recognizing water quality parameters and blue-green algae's abundance characteristics solely by selecting limited remote sensing reflectance with a specific wave length. Comprehensive methodology enriches the content of lake telemetry technology by continuous, more precise, and more common remote sensing monitoring.

\section{References}

1. TRESCOTT A. Remote Sensing Models of Algal Blooms and Cyanobacteria in Lake Champlain, Environmental \& Water Resources Engineering, University of Massachusetts Amherst. ScholarWorks@UMass Amherst, Masters Projects Civil and Environmental Engineering, 2012.

2. VAHTMAE E., KUTSER T., KOTTA J., PARNOJA M. Detecting patterns and changes in a complex benthic environment of the Baltic Sea. Journal of Applied Remote Sensing 5 (1), 053559-1, 2011.

3. PÉREZ G., QUEIMALIÑOS C., BALSEIRO E., MODENUTTI B. Phytoplankton absorption spectra along the water column in deep North Patagonian Andean lakes (Argentina). Limnologica - Ecology and Management of Inland Waters, 37 (1), 3, 2007.

4. SOSIK H.M. Characterizing seawater constituents from optical properties, In M. Babin, C.S. Roesler, J. J. Cullen [eds.]. Real-time coastal observing systems for ecosystem dynamics and harmful algal blooms. UNESCO, 281, (peer reviewed), 2008

5. SIMIS S.G.H., RUIZ-VERDÚ A., DOMÍNGUEZ-GÓMEZ J.A., PEÑA-MARTINEZ R., PETERS S.W.M., GONS H. J. Influence of phytoplankton pigment composition on remote sensing of cyanobacterial biomass, Remote Sensing of Environment, 106 (4), 414, 28 February 2007.

6. BLAHA L., BABICA P., MARŠÁLEK B. Toxins produced in cyanobacterial water blooms - toxicity and risks. Interdisciplinary Toxicology, 2 (2), 36, 2009.

7. JEKATIERYNCZUK-RUDCZYK E. ZIELIŃSKI P., GRABOWSKA M., EJSMONT-KARABIN J., KARPOWICZ M., WIĘCKO A. The trophic status of Suwałki Landscape Park lakes based on selected parameters (NE Poland). Environmental Monitoring and Assesment, 186 (8), 5101, 2014.

8. YOUNG F.M., MICKLEM J., HUMPAGE A.R. Effects of blue-green algal toxin cylindrospermopsin (CYN) on human granulosa cells in vitro. Reprod. Toxicol, 25, 374, 2008.

9. KARGI F., PAMUKOGLU Y. Aerobic biological treatment of pre-treated landfill leachate by fed-batch operation. Enzyme and Microbial Technology, 33 (5) 588, 2003.

10. FUNARI E., TESTAI E. Human Health Risk Assessment Related to Cyanotoxins Exposure. Critical Reviews in Toxicology, 38, 97, 2008.

11. Health Effects Support Document for the Cyanobacterial Toxin Cylindrospermopsin U.S. Environmental Protection 
Agency Office of Water (4304T), Health and Ecological Criteria Division, Washington, DC 20460, EPA Document Number: 820R15103, 2015.

12. JAKUBOWSKA N., SZELĄG-WASIELEWSKA E. "Toxic Picoplanktonic Cyanobacteria - Review.” Mar. Drugs 13 (3), 1497, 2015.

13. CHORUS I., BERTRAM J. [Eds.] Toxic Cyanobacteria in Water, E \& FN SPON, London, New York, 1999.

14. MULVENNA V., DALE K., PRIESTLY B., MUELLER U., HUMPAGE A., SHAW G., ALLINSON G., FALCONER I. Health Risk Assessment for Cyanobacterial Toxins in Seafood. Int. J. Environ. Res. Public Health, 9 (3), 807, 2012.

15. JAKUBOWSKA N., ZAGAJEWSKI P., GOŁDYN R. Water Blooms and Cyanobacterial Toxins in Lakes, Polish Journal of Environmental Studies, 22 (4), 1077, 2013.

16. KOBOS J., BŁASZCZYKA., HOHLFELD N., TORUŃSKA A., SITARZA., KRAKOWIAKA., HEBELA., SUTRYK K., GRABOWSKA M., TOPOROWSKA M., KOKOCIŃSKI M., MESSYASZ B., RYBAK A., NAPIÓRKOWSKA A., KRZEBIETKE, NAWROCKA L., PEŁECHATA A., BUDZYŃSKA A., ZAGAJEWSKI P., MAZUR-MARZEC H. Cyanobacteria and cyanotoxins in Polish freshwater bodies, Oceanological and Hydrobiological Studies, International Journal of Oceanography and Hydrobiology, 42 (4), 358, 2013.

17. GRABOWSKA M., MAZUR-MARZEC H. The effect of cyanobacterial blooms in the Siemianówka Dam Reservoir on the phytoplankton structure in the Narew River, Oceanol. Hydrobiol. Stud., 40 (1), 19, 2011.

18. CHRÓST J.R. Ocena aktualnego stanu jakości ekologicznej wód oraz analiza zagrożeń eutrofizacyjnych systemu Jeziora Śniardwy, Zakład Ekologii Mikroorganizmów , Uniwersytet Warszawski, Lokalna Grupa Działania „Mazurskie Morze”, 2012.

19. HAIDER S., VIJAY N., VISWANATHAN P. N., KAKKAR P. Cyanobacterial toxins: a growing environmental concer, Chemosphere, 52, 1-21, 2003.

20. KURMAYER R., SCHOBER E., TONK L., VISSER P.M., CHRISTIANSEN G. Spatial divergence in the proportions of the genes encoding toxic peptides synthesis among populations of the cyanobacterium Planktothrix in European lakes, FEMS Microbiol. Lett. 317, 127-137, 2011.

21. GRABOWSKA M., KOBOS J., TORUŃSKA-SITARZ A., MAZUR-MARZEC H. Non-ribosomal peptides produced by Planktothrix agardhii from Siemianówka Dam Reservoir SDR (northeast Poland), Archives of Microbiology, 2014.

22. KOBOS J., MAZUR-MARZEC H., DITTMER M., WITEK B., PLIŃSKI M. Toxic cyanobacterial blooms in the Kociewskie Lasek (Northern Poland), Oceanol. Hydrobiol. Stud. 34 (3), 77, 2005.

23. REPKA S., MEYERHÖFER M., VON BRÖCKEL K., SIVONEN K. Associations of cyanobacterial toxin, nodularin, with environmental factors and zooplankton in the Baltic Sea. Microb. Ecol., 47, 350. 2004.

24. KURMAYER R., DITTMAN E., FASTNER J., CHORUS I. Diversity of microcystin genes within a population of the toxic cyanobacterium Microcystis spp. in Lake Wannsee (Berlin, Germany), Microb. Ecol. 43, 107, 2002.

25. HESSE K., KOHL J.G. Effects of light and nutrient supply on growth and microcystin content of different strains of Microcystis aeruginosa. In I. Chorus (Ed.) Cyanotoxins. Occurrence, causes, consequences. Springer, Berlin. 104, 2001.

26. BŁASZCZYK A. Cyanobacterial neurotoxins in the environment of the Baltic Sea and the lakes of Pomerania
Province. Unpublished doctoral dissertation, University of Gdańsk, Gdynia, Poland. (in Polish with Engl. summ.), 2011.

27. GALICKA W., LESIAK T., RAKOWSKA B., Dynamics of blue-green algae development in Sulejów Dam Reservoir. Oceanol. Stud. 1, 21, 1998.

28. GĄGAŁA I., IZYDORCZYK K., SKOWRON A., KAMECKA-PLASKOTA D., STEFANIAK K., KOKOCIŃSKI M., MANKIEWICZ-BOCZEK J. Appearance of toxigenic cyanobacteria in two Polish lakes dominatem by Microcystis aeruginosa and Planktothrix agardhii and environmental factors influence. Ecohydrol. Hydrobiol. 10 (1), 25, 2010.

29. GŁOWACKA J., SZEFEL-MARKOWSKA M., WALERON M., ŁOJKOWSKA E., WALERON K. Detection and identyfication of potentially toxic cyanobacteria in Polish water bodies. Acta Biochim. Pol. 58 (3), 321, 2011.

30. GRABOWSKA M., PAWLIK-SKOWROŃSKA B. Replacement of Chroococcales and Nostocales by Oscillatoriales caused a significant increase in microcystin concentrations in a dam reservoir. Oceanol. Hydrobiol. Stud., 37 (4), 23, 2008.

31. GRABOWSKA M., MAZUR-MARZEC H. The effect of cyanobacterial blooms in the Siemianówka Dam Reservoir on the phytoplankton structure in the Narew River. Oceanol. Hydrobiol. Stud. 40 (1), 19, 2011.

32. KALINOWSKA R., PAWLIK-SKOWRONSKA B., SKOWRONSKI T. Hazardous change in the species composition of cyanobacterial assemblage in the autrophic dam reservoir in Lublin (E. Poland). 31st International Conference of the Polish Phycological Society, Olsztyn, 17$20^{\text {th }}$ May, 44, 2012.

33. KABZIŃSKI, A.K. M., JUSZCZAK R. MIĘKOŚ E., TARCZYŃSKA M., SIVONEN K., RAPALA J. The first report about the presence of cyanobacterial toxins in Polish lakes. Polish J. Environ. Stud. 9 (3), 171, 2000.

34. JEKATIERYNCZUK-RUDCZYK E., GRABOWSKA M., EJSMONT-KARABIN J., KARPOWICZ M. Assessment of trophic state of four lakes in the Suwałki Landscape Park (NE Poland) based on the summer phyto- and zooplankton in comparison with some physicochemical parameters. In K. Wołowski, I. Kaczmarska, J. Ehrman, A. Z. Wojtal (Eds.) Phycological Reports: Current advances in algal taxonomy and its applications: phylogenetic, ecological and applied perspective. Instytut Botaniki im. W. Szafera, Kraków, 205, 2012.

35. BUCKA H., WILK-WOŹNIAK E. Cyanobacteria responsible for planktic water blooms in reservoirs in southern Poland. Algological Studies 94, 105, 1999.

36. KOBOS J., MAZUR-MARZEC H., DITTMER M., WITEK B., PLIŃSKI M. Toxic cyanobacterial blooms in the Kociewskie Lasek (Northern Poland). Oceanol. Hydrobiol. Stud. 34 (3), 77, 2005.

37. KOBOS J. Characterisctics of toxic and potentially toxic cyanobacteria occurring in the Gulf of Gdańsk and selected lakes from the Radunia River drainage. Unpublished doctoral dissertation, University of Gdańsk, Gdynia, Poland. (in Polish with Engl. summ.), 2007.

38. KOKOCIŃSKI M., DZIGA D., SPOOF L., STEFANIAK K., JURCZAK T., MANKIEWICZ-BOCZEK J., MERILUOTO J. First report of the cyanobacterial toxin cylindrospermopsin in the shallow, eutrophic lakes of western Poland. Chemosphere, 74, 669, 2009.

39. KOKOCIŃSKI M., STEFANIAK K., MANKIEWICZBOCZEK J., IZYDORCZYK K., SOININEN J. The ecology of the invasive cyanobacterium Cylindrospermopsis 
raciborskiii (Nostocales, Cyanophyta) in two hypereutrophic lakes dominated by Planktothrix agardhii (Oscillatoriales, Cyanophyta). Eur. J. Phycol. 45 (4), 365, 2010.

40. MANKIEWICZ J., WALTER Z., TARCZYNSKA M., PALYVODA O., WOJTYSIAK-STANISZCZYK M., ZALEWSKI M. Genotoxicity of cyanobacterial extracts containing microcystins from Polish water reservoirs as determined by SOS chromotest and comet assay. Environ. Toxicol. 17, 341, 2002.

41. MANKIEWICZ, J., KOMÁRKOVÁ J., IZYDORCZYK K., JURCZAK T., TARCZYŃSKA M., ZALEWSKI M. Hepatotoxic cyanobacterial blooms in the lakes of Northern Poland. Environ. Toxicol. 20, 499, 2005.

42. BUCKA H., WILK-WOŹNIAK E. A contribution to the knowledge of some potentially toxic cyanobacteria species forming blooms in water bodies - chosen examples. Oceanol. Hydrobiol. Stud. 34 (3), 43, 2005.

43. MESSYASZ B. Fitoplankton. Wykaz gatunków sinic i glonów planktonowych (2004-2006). In L. Burchardt (Ed.) Jezioro Lednica. Historyczne i wspołczesne funkcjonowanie ekosystemu wodnego. Kwartet, 225, 2011.

44. MANKIEWICZ-BOCZEK J., IZYDORCZYK K., JURCZAK T. Risk assessment of toxic Cyanobacteria in Polish water bodies. In A. G. Kungolos, C. A. Brebbia, C. P. Samaras \& V. Popov (Eds.) Environmental Toxicology. WIT Transactions on Biomedicine and Health, WITpress, Southampton, Boston, 10, 49, 2006.

45. MANKIEWICZ-BOCZEK J., KOKOCIŃSKI M., GAGAŁA I., PAWEŁCZYK J., JURCZAK T., DZIADEK J. Preliminary Molecular Identification of Cylindrospermopsinproducing Cyanobacteria in Two Polish Lakes (Central Europe). FEMS Microbiol. Lett. 326, 173, 2012.

46. MAZUR H., LEWANDOWSKA J., BŁASZCZYK A., KOT A., PLINSKI M. Cyanobacterial toxins in fresh and brackisch waters of Pomorskie Province (Northern Poland). Oceanol. Hydrobiol. Stud., 32 (1), 15, 2003.

47. MAZUR-MARZEC H., SPOOF L., KOBOS J., PLIŃSKI M., MERILUOTO J., Cyanobacterial hepatotoxins, microcystins and nodularins, in fresh and brackish waters of Pomeranian Province, northern Poland. Oceanol. Hydrobiol. Stud. 37 (4), 1, 2008.

48. MAZUR-MARZEC H., BŁASZCZYK A., BŁOŃSKA M., CICHOWSKA A., KOBOS J., SUTRYK K., TORUŃSKA A., PLIŃSKI M. Cyanobacterial blooms and cyanotoxin production in the Baltic Sea and the lakes of Pomeranian Province. In K. Olańczuk-Neyman \& H. Mazur-Marzec (Eds.) Microorganisms in the environment and environmental engineering. From ecology to technology. Monografie Komitetu Inżynierii Środowiska PAN, 64, 159, 2010.

49. PAWLIK-SKOWROŃSKA B., SKOWROŃSKI T., PIRSZEL J., ADAMCZYK A. Relationship between cyanobacterial bloom composition and anatoxin-a and microcystin occurrence in the eutrophic dam reservoir (SE Poland). Pol. J. Ecol. 52 (4), 479, 2004.

50. PAWLIK-SKOWROŃSKA B., KORNIJÓW R., PIRSZEL J., Sedimentary imprint of cyanobacterial blooms - a new tool for insight into recent history of lakes. Pol. J. Ecol. 58 (4), 663, 2010.

51. PAWLIK-SKOWROŃSKA B., TOPOROWSKA M. Blooms of toxin-producing cyanobacteria- a real threat in small dam reservoirs at the beginning of their operation. Oceanol. Hydrobiol. Stud. 40 (4), 30, 2011.

52. PAWLIK-SKOWROŃSKA B., TOPOROWSKA M., SKOWROŃSKI T. Cyanobacterial blooms, cyanotoxins and their accumulation in ichthyofauna of Zemborzycki dam reservoir (E. Poland). 30th International Conference of the
Polish Phycological Society. Wrocław-Pawłowice, Poland, 19-21 ${ }^{\text {st }}$ May, 2011.

53. PAWLIK-SKOWROŃSKA B., TOPOROWSKA M. Blooms of toxigenic cyanobacteria in four regulated lakes in the Wieprz-Krzna chanel system (Łęczyńsko-Włodawskie Lakeland). Conference Function, threat and protection of small water bodies, Janów Lubelski, 25-29 $9^{\text {th }}$ September, (in Polish); 2013.

54. PEŁECHATA A., WALNA B., PEŁECHATY M., KACZMAREK L., OSSOWSKI P., LORENC M. Seasonal dynamics of the algae and blue-green assemblage of Góreckie Lake against the background of the physical-chemical properties of water and the development of macrophytes. In B. Walna, L. Kaczmarek, M. Lorenc \& R. Dondajewska (Eds.) Wielkopolski Park Narodowy w badaniach przyrodniczych, 27-42, Poznań-Jeziory (in Polish with Engl. summ.), 2009.

55. RAKOWSKA B., SITKOWSKA M., SZCZEPOCKA E., SZULC B. Cyanobacteria water blooms with various eucariotic algae in the Sulejów Reservoir. Oceanol. Hydrobiol. Stud. 34 (1), 31, 2005.

56. SIEROSŁAWSKA A., RYMUSZKA A., KALINOWSKA R., SKOWROŃSKI T., BOWNIK A., PAWLIK-SKOWROŃSKA B. Toxicity of cyanobacterial bloom in the eutrophic dam reservoir (Southeast Poland). Environ. Toxicol. Chem. 29, 556, 2010.

57. SOLIS M., PONIEWOZIK M., MENCFEL R. Bloomforming cyanobacteria and other algae in selected anthropogenic reservoirs of the Łęczna-Włodawa Lakeland. Oceanol. Hydrobiol. Stud. 38 (2), 71, 2009.

58. STEFANIAK K., KOKOCIŃSKI M. Occurrence of invasive cyanobacteria species in polimictic lakes of the Wielkopolska region (Western Poland). Oceanol. Hydrobiol. Stud. 34 (3), 137, 2005.

59. WILK-WOŹNIAK E., BUCKA H. Species diversity of algae and cyanobacteria in phytoplankton communities on the example of history of Roźnów dam reservoir. A review. Pol. Arch. Hydrobiol. 47 (2), 213, 2000.

60. ZAGAJEWSKI P., GOŁDYN R., FABIŚ M. Cyanobacterial volume and microcystin concentration in recreational lakes (Poznań - Western Poland). Oceanol. Hydrobiol. Stud. 38 (2), 113, 2009.

61. MANKIEWICZ-BOCZEK J., IZYDORCZYK K., ROMANOWSKA-DUDA Z., JURCZAK T., STEFANIAK K., KOKOCIŃSKI M. Detection and monitoring toxigenicity of cyanobacteria by application of molecular methods, Environ. Toxicol., 21, 380-, 2006a.

62. MANKIEWICZ-BOCZEK J., URBANIAK M., ROMANOWSKA-DUDA Z., IZYDORCZYK K. Toxic Cyanobarteria strains in lowland dam reservoir (Sulejow Res., Central Poland): Amplification of mcy genes for detection and identification, Pol. J. Ecol. 53 (2), 1, 2006b.

63. RANTALA A., RAJANIEMI-WACKLIN P., LYRA C., LEPISTO L., RINTALA J., MANKIEWICZ-BOCZEK J., SIVONEN K. Detection of microcystin-producing cyanobacteria in Finnish lakes with genus-specific microcystin synthetase gene E (mcyE) PCR and associations with environmental factors: Appl. Environ. Microbiol. 72, 6101, 2006.

64. BOUTTE C., MANKIEWICZ-BOCZEK J., KOMARKOVA J., GRUBISIC S., IZYDORCZYK K., WAUTELET F., JURCZAK T., ZALEWSKI M., WILMOTTE A., Diversity of planktonic cyanobacteria and microcystin occurrence in Polish water bodies investigated using a polyphasic approach, Aquat Microb Ecol 51, 223, 2008. 
65. SRIVASTAVA P., BHAMBRI R., KAWISHWAR P., DOBHAL D.P. Water level changes of high altitude lakes in Himalaya-Karakoram from ICES at altimetry, J. Earth Syst. Sci. 122 (6), 1533, 2013

66. GACGAŁA I., IZYDORCZYK K., JURCZAK T., PAWEŁCZYK J., DZIADEK J., WOJTAL-FRANKIEWICZ A., JÓŹWIAK A., JASKULSKA A., MANKIEWICZBOCZEK J. Role of Environmental Factors and Toxic Genotypes in the Regulation of Microcystins-Producing Cyanobacterial Blooms, Microb Ecol., 67, 465, 2014.

67. SATHYENDRANATH S. (Plymouth Marine Laboratory), Reports and Monographs of the International Ocean-Colour Coordinating Group, Phytoplankton Functional Types from Space, An Affiliated Program of the Scientific Committee on Oceanic Research (SCOR) An Associated Member of the (CEOS), IOCCG Report Number 15, 2014.

68. HALLEGRAEFF G.M., ANDERSON D.M., CEMBELLA A.D. Manual on Harmful Marine Microalgae Edited by H.O. Enevoldsen, UNESCO, 2004.

69. HALINEN K., JOKELA J., FEWER D.P., WAHLSTEN M., SIVONEN K. Direct evidence for production of microcystins by Anabaena strains from the Baltic Sea. Appl Environ Microbiol 73, 6543, 2007.

70. SOBIECHOWSKA-SASIM M., STOŃ-EGIERT J., KOSAKOWSKA A. Quantitative analysis of extracted phycobilin pigments in cyanobacteria - an assessment of spectrophotometric and spectrofluorometric methods, J Appl Phycol. 26 (5), 2065, 2014.

71. MRÓZ W. Monitoring siedlisk przyrodniczych. Przewodnik metodyczny. Cz. II, GIOŚ, Warszawa, 2012.

72. Directive 2000/60/EC of the European Parliament and of the Council of 23 October 2000.

73. Regulation of the Minister of Environment of 13 May 2009 on forms and methods of conducting surface water and groundwater monitoring (OJ of 2009 No. 81, item. 685), from 15th of November 2011 a new regulation came with the same title (OJ of 2011 No 258, item. 1550), 2009.

74. Water Law Acts, 2001.

75. HARRINGTON J.A Jr., SCHIEBE F.R., NIX J.F. Remote sensing of Lake Chicot, Arkansas: Monitoring suspended sediments, turbidity, and secchi depth with Landsat MSS data. Remote Sens. Environ. 39, 15, 1992.

76. MERTES L.A.K., SMITH M.O., ADAMS J.B. Estimating suspended diment concentrations in surface waters of the Amazon River wetlands from Landsat images. Remote Sens. Environ. 43, 281, 1993.

77. RITCHIE J.C., COOPER C.M., YONGQING J. Using Landsat Multispectral scanner data to estimate suspended sediments in Moon Lake, Mississippi. Remote Sens. Environ. 23, 65, 1987.

78. BRACHER A., HARDMAN-MOUNTFORD N., HIRATA T., BERNARD S., BREWIN R., BRICAUD A., BROTAS V., CHASE A., CIOTTI A., CHOI J. K., CLEMENTSON L., DEVRED E., DIGIACOMO P, DUPOUY C., KIM W., KOSTADINOV T., KWIATKOWSKA E., LAVENDER S., MOISAN T., MOUW C., SON S., SOSIK H, UITZ J., WERDELL J., ZHENG G. Phytoplankton Composition from Space: towards a validation strategy for satellite algorithms, Report on IOCCG workshop, Holiday Inn By-the-Bay, Portland, Maine, USA, October 25-26, 2014.

79. LESHKEVICH G., SHUCHMAN R.A., SAYERS M.J. An Operational Algorithm to Retrieve Chlorophyll, DOC, and Suspended Minerals from Satellite Data of the Great Lakes, Proceedings, European Space Agency (ESA) 3rd MERIS/ Sentinel-3 Symposium ESA-ESRIN, Franscati, Italy, October 15-19, 2012.

80. WAXTER M.T. Analysis of Landsat Satellite Data to Monitor Water Quality Parameters in Tenmile Lake, Oregon, Portland State University, PDXScholar, Civil and Environmental Engineering Master's, Project Reports Civil and Environmental Engineering, 2014.

81. COLOMINA I., MOLINA P. Unmanned aerial systems for photogrammetry and remote sensing: A review, ISPRS Journal of Photogrammetry and Remote Sensing, 92, 79, 2014.

82. TELLIDIS I., LEVIN E. Photogrammetric Image Acquisition with Small Unmanned Aerial Systems, ASPRS 2014 Annual Conference Louisville, Kentucky, March 23-28, 2014.

83. CAMPBELL J. E., SHIN M. Satellite Imagery and Aerial Photography", section 4.3 from the book Geographic Information System Basics (v. 1.0), 2012. 
